\title{
Push-down Accounting: A Comprehensive Case Study
}

Peter Harris, New York Institute of Technology, USA

\begin{abstract}
Push-down Accounting has gained great popularity over the last decade with the resurrection of acquisitions and the increased global expansion of business activities. The U.S. Securities and Exchange Commission (SEC) recommends Push-down accounting, where appropriate, as it is an easier and more effective method of financial reporting than the complex structure of intercompany elimination entries. The ending reported consolidated amounts are also identical whether this method is used or not. This case study provides the criteria for Push-down and details an actual case study of its preparation and presentation of a balance Sheet on the date of acquisition.
\end{abstract}

Keywords: Push-Down Accounting; Push-Down Capital; Consolidated Balance Sheet On The Date Of Acquisition

\section{INTRODUCTION}

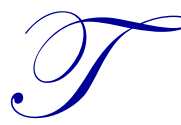

his case study will provide a thorough illustration of the concepts of Push-down Accounting. An overview of this critical topic will be discussed, followed by a comprehensive illustration demonstrating the results of Push-down application to both - the acquired entity as well as to the consolidated group - as of the date of acquisition (which is the same regardless of its use). In recent years, Pushdown Accounting has drawn increased attention to the accounting bodies including the U.S. Generally Accepted Accounting Principals (US GAAP) and the International Financial Reporting Standards (IFRS), as well as to the SEC. As such, its treatment is not uniform and allows for some flexibility at this time. The solutions presented here are in the author's opinion - the most correct from an accounting theoretical viewpoint - bur alternate solutions yielding materially similar solutions exist. This case study is recommended as a group project for an Advanced Accounting course, as well as for a graduate Financial Statement Analysis class.

\section{FACTS}

On December 31, 2011, PA. Inc. purchased 95 percent of Sub. Inc. for $\$ 120,000$ cash. The Balance Sheet of each corporation, just prior to the acquisition, is presented below. Additionally, book value and fair value for all of Sub's assets and liabilities are equal, with the exception of Property and Plant and Equipment, whose fair value is $\$ 47,000$. 


\begin{tabular}{|c|c|c|c|c|}
\hline \multirow[b]{3}{*}{ Assets } & \multicolumn{2}{|r|}{ PA Inc. } & \multicolumn{2}{|c|}{ SUB Inc. } \\
\hline & \multicolumn{4}{|c|}{ Balance Sheet } \\
\hline & \multicolumn{2}{|c|}{$12 / 31 / 2011$} & \multicolumn{2}{|c|}{$12 / 31 / 2011$} \\
\hline \multicolumn{5}{|l|}{ Current Assets } \\
\hline Cash & $\$$ & 170,000 & $\$$ & 21,000 \\
\hline Accounts Receivable (Net) & & 60,000 & & 45,000 \\
\hline Inventory & & 50,000 & & 45,000 \\
\hline Total Current Assets & $\$$ & 280,000 & $\$$ & 111,000 \\
\hline \multicolumn{5}{|l|}{ Fixed Assets } \\
\hline Property, Plant, and Equipment (Net of Accumulated Depreciation) & & 265,000 & & 42,000 \\
\hline \multicolumn{5}{|l|}{ Goodwill } \\
\hline Total Assets & & 545,000 & & 153,000 \\
\hline \multicolumn{5}{|l|}{ Liabilities } \\
\hline \multicolumn{5}{|l|}{ Current Liabilities } \\
\hline Accounts Payable & $\$$ & 70,000 & $\$$ & 30,000 \\
\hline Accruals Payable & & 20,000 & & 15,000 \\
\hline Total Current Liabilities & $\$$ & 90,000 & $\$$ & 45,000 \\
\hline \multicolumn{5}{|l|}{ Non-Current Liabilities } \\
\hline \multicolumn{5}{|l|}{ Bonds Payable } \\
\hline Total Liabilities & $\$$ & 270,000 & $\$$ & 45,000 \\
\hline \multicolumn{5}{|l|}{ Shareholders' Equity } \\
\hline Non-Controlling Interest (Share of Subsidiary) & $\$$ & & $\$$ & \\
\hline Common Stock (\$5 Par) & & 100,000 & & 55,000 \\
\hline Paid In Capital & & 20,000 & & 8,000 \\
\hline Retained Earnings & & 155,000 & & 45,000 \\
\hline Total Shareholders' Equity & $\$$ & 275,000 & $\$$ & 108,000 \\
\hline Total Liabilities and Shareholder's Equity & $\$$ & 545,000 & $\$$ & 153,000 \\
\hline
\end{tabular}

\section{REQUIRED}

1. Calculate the amount of Goodwill implicit in this purchase.

2. Discuss the requirements and criteria underlying Push-down Accounting.

3. Prepare the recording of the purchase by the parent company, assuming the Push-down accounting method is applied.

4. Prepare necessary adjustment entries to satisfy the Push-down accounting requirements.

5. Prepare a Balance Sheet for Sub. Inc. immediately after this acquisition on 12/3/2011.

6. Prepare a consolidated Balance Sheet immediately after this acquisition on 12/21/2011.

\section{RECOMMENDED SOLUTIONS}

\section{Goodwill Calculation}

Goodwill will equal the excess value of the company's net identifiable net assets. In this situation, the value of Sub Inc. is the purchase amount paid by PA, divided by the share of ownership interest, calculated as follows: $\$ 120,000 / .95=\$ 126,316$. The identifiable net assets of Sub Inc. are its Shareholders' Equity book value, plus or minus fair value adjustments. In this case, the only fair value adjustment is an increase in Property and Plant and Equipment by $\$ 5,000(47,000-42,000)$, making the fair value of Bub's identifiable net assets equal to $\$ 108,000$ plus 5,000 , or $\$ 113,000$. Goodwill will thus equal $\$ 126,316$ less 113,000 , or $\$ 13,316$. 


\section{Push-down Accounting Requirements}

Push-down refers to a situation whereby fair value adjustments associated with an acquisition are transacted in the subsidiary's accounting records rather than through elimination entries toward the consolidated financial statement process. The effect is to restate balance sheet accounts at fair value as of the date of acquisition known as a step-up value. Push-down is a requirement under SEC rules if the following conditions exist:

A. The acquisition percentage is at least 90 percent.

B. The acquired subsidiary has no outstanding public debt.

C. The acquired subsidiary has no outstanding preferred stock.

The SEC recommends Push-down in all instances, but it is mandatory if the above three conditions are met.

It is important to understand that the consolidated financial statements will be the same regardless of the choice to use - or not use - the Push-down accounting method. The consolidation accounting process, however, is greatly simplified by its use.

\section{Purchase of Subsidiary Journal Entry}

Dr. Investment in Sub $\quad 120,000$ Cr. Cash 120,000

This transaction brings the cash balance in PA down to $\$ 50,000$.

\section{Prepare Necessary Adjustment Entries To Satisfy The Push-down Accounting Requirements}

Sub. Inc. will realize the effects of the purchase made by PA Inc., which will create a new financial position the day of acquisition. Sub's assets and liabilities will be reflected at fair values (including goodwill) and the Retained Earnings will be decreased to a zero balance. The difference in the above transaction will be plugged into a newly created account called Push-down Capital.

$\begin{array}{lr}\text { Dr. Property, Plant and Equipment } & 5,000 \\ \text { Dr. Goodwill } & 13,316 \\ \text { Dr. Retained Earnings } & 45,000\end{array}$

Cr. Push-down Capital

63,316 
5. Prepare A Balance Sheet For Sub. Inc. Immediately After Acquisition On 12/31/2011

\begin{tabular}{|c|c|c|}
\hline Assets & & 12/31/2011 \\
\hline Current Assets & & \\
\hline Cash & $\$$ & 21,000 \\
\hline Accounts Receivable (Net) & & 45,000 \\
\hline Inventory & & 45,000 \\
\hline Total Current Assets & $\$$ & 111,000 \\
\hline Fixed Assets & & \\
\hline Property, Plant, and Equipment (Net of Accumulated Depreciation) & & 47,000 \\
\hline Goodwill & & 13,316 \\
\hline Total Assets & & 171,316 \\
\hline Liabilities & & \\
\hline Current Liabilities & & \\
\hline Accounts Payable & $\$$ & 30,000 \\
\hline Accruals Payable & & 15,000 \\
\hline Total Current Liabilities & $\$$ & 45,000 \\
\hline Non-Current Liabilities & & \\
\hline Bonds Payable & & \\
\hline Total Liabilities & $\$$ & 45,000 \\
\hline Shareholders' Equity & & \\
\hline Non-Controlling Interest (Share of Subsidiary) & $\$$ & \\
\hline Common Stock (\$5 Par) & & 55,000 \\
\hline Paid In Capital & & 8,000 \\
\hline Retained Earnings & & \\
\hline Push-down Capital & & 63,316 \\
\hline Total Shareholders' Equity & $\$$ & 126,316 \\
\hline Total Liabilities and Shareholder's Equity & $\$$ & $\mathbf{1 7 1 , 3 1 6}$ \\
\hline
\end{tabular}




\section{Prepare A Consolidated Balance Sheet Immediately After Acquisition On 12/21/2011}

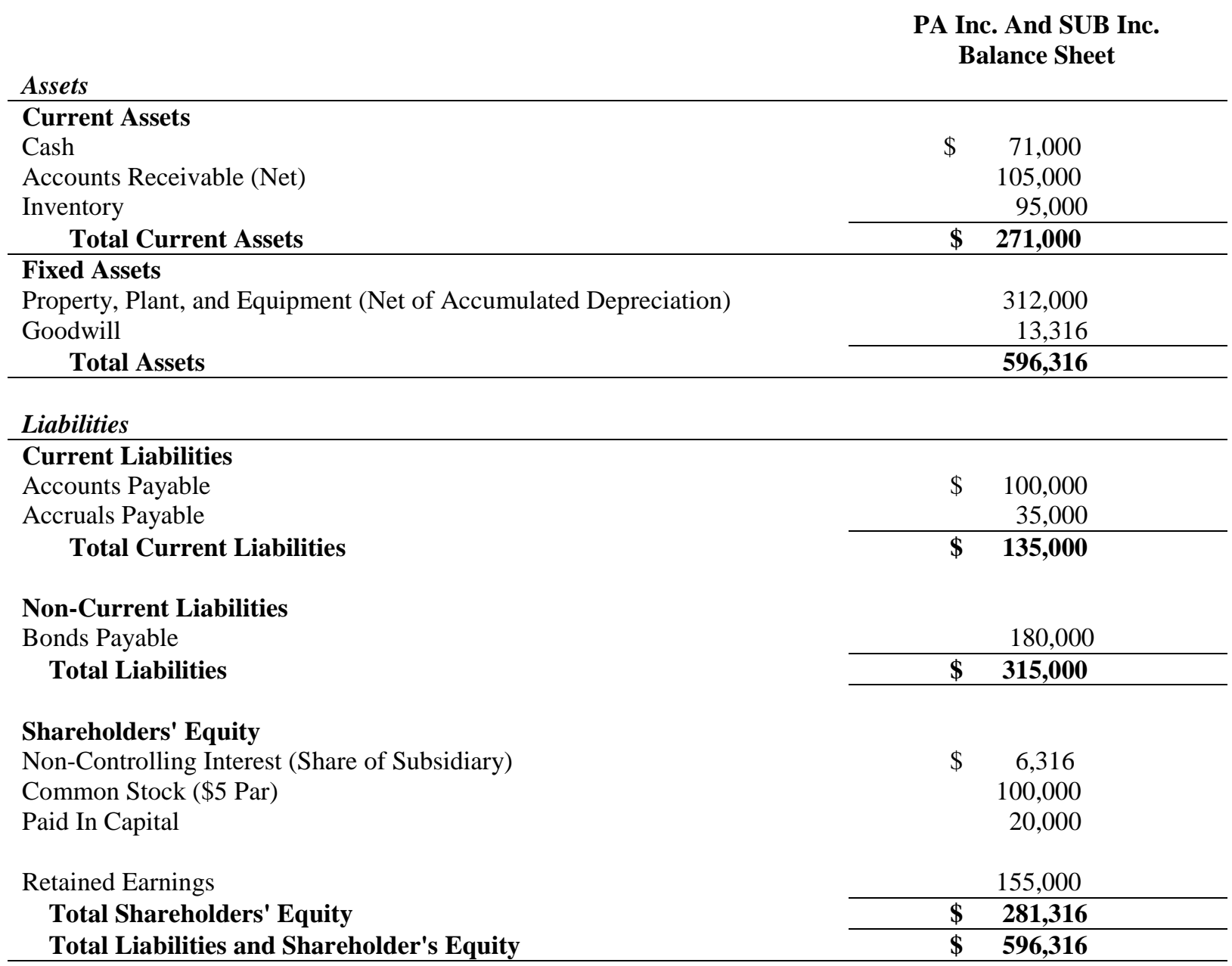

\section{Notes:}

The consolidated worksheet elimination entries are as follows:
Dr. Common Stock-Sub 55,000
Dr. Paid In Capital-Sub
8,000
Dr. Push-down Capital
63,316
Cr. Investment in Sub
120,000
Cr. Non-controlling Interest in Sub
6,316 (126,316 times 5 percent)

\section{CONCLUSION}

This case study introduced the student to the concepts of Push-down Accounting, as well as to the consequences of its use. At the outset, the definition of Push-down accounting and the requirements of its use were discussed in detail. A comprehensive illustration was then provided, resulting in a Balance Sheet presentation of the acquired subsidiary, as well as to the consolidated group. Compliant journal entries necessary to record the purchase of the subsidiary, the Push-down requirements for the subsidiary, as well as the consolidated worksheet elimination entries, were provided toward the presentation of the Balance Sheets. A follow-up case study on Push-down Accounting after the acquisition date is highly recommended. Additionally, a case study illustrating the effects of 
consolidation on the date of acquisition, where the Push-down Accounting method is not utilized, should be presented.

\section{AUTHOR INFORMATION}

Peter Harris is a Professor and Chair of the Accounting and Finance department at the New York Institute of Technology. Previously, he has worked for Ernst and Young LLP. He is an author of over 50 refereed journal articles and over 150 intellectual contributions. He can be reached at pharris@ nyit 